\title{
AGE OF MORAINES IN VICTORIA LAND, ANTARCTICA*
}

\author{
By Troy L. PÉwé \\ (U.S. Geological Survey and Department of Geology, University of Alaska, \\ College, Alaska)
}

\begin{abstract}
Fresh-looking" moraines lying within a mile of glaciers in the lowlands of the McMurdo Sound area, Victoria Land, Antarctica have been interpreted by some to be only 50 or 100 yr. old and to have been left by recent glacier retreats. The present author believes that these moraines are considerably older because a comparison of the position of existing glacier fronts in the area with positions on photographs of 5o $\mathrm{yr}$. ago shows no movement of the front or appreciable thickening or thinning of the glaciers during the last $50 \mathrm{yr}$.

Radiocarbon dating of mummified seal carcasses lying near glacier fronts indicates that the glaciers have not been more extensive for at least 1 , ooo $\mathrm{yr}$. The youngest moraines in the area are ice-cored moraines to the existing glaciers. Radiocarbon dates of algae from extinct ephemeral ponds in the ice-cored moraines indicate the moraines to be at least 6,000 yr. old.

Additional evidence for the antiquity of the near-glacier moraines is the presence of a rather uniformly well-developed micro-relief pattern of sand-wedge polygons on both the end moraines and the ground moraines extending up to the existing glacier front. Studies show that it requires hundreds if not thousands of years for such well-developed polygonal patterns to form.
\end{abstract}

RÉsumÉ. On avait pensé que les moraines “d'apparence fraîche"' se trouvant à moins d'un mile ( $\mathrm{r}, 6 \mathrm{~km}$.) des glaciers des basses terres du Détroit de McMurdo et de la Terre de Victoria, dans l'Antarctique, ne sont pas plus agées que 50 ou 100 ans et avaient été déposées lors de la récente régression des glaciers. L'auteur croit que ces moraines sont beaucoup plus vieilles car la comparaison de photographies récentes avec des photographies de la région prises il y a 50 ans, ne montre aucun changement des fronts, ni variation appréciable de l'épaisseur des glaciers au cours de ces 50 dernières années.

Le datage par radio-carbone de carcasses de phoques momifiés, gisant près des fronts des glaciers, indique que ces fronts n'ont pas été plus étendus depuis au moins I ooo ans. Les moraines les plus récentes de la région sont des moraines à noyaux de glace se trouvant sur les glaciers actuels. Les datages par radio-carbone d'algues prélevées dans les moraines à noyaux de glace, à l'emplacement d'etangs éphémères disparus, prouvent que ces moraines sont au moins vieilles de 6 ooo ans.

De plus, la présence d'un micro-relief assez-bien développé partout, formé de figures polygonales dont les angles sont constitués de dépôts de sable sur les moraines frontales et les moraines de fond, s'étendant jusqu'au front actuel du glacier, prouve que les moraines proches du glacier datent de l'antiquité. Les études faites montrent qu'il faut des siècles, sinon des millénaires, pour former des figures polygonales aussi bien développées.

Zusammenfassung. "Recente" Moränen, die im Bereich von etwa einer Meile $(1,6 \mathrm{~km}$.) vor Gletschern im Unterland des McMurdo-Sund-Gebietes (Victoria-Land, Antarktis) liegen, wurden von einigen Autoren als junge Rückzugsmoränen mit einem Alter von nur 50 oder oo Jahren gedeutet. Der Verfasser hält jedoch diese Moränen für beträchtlich älter, weil ein Vergleich der heutigen Lage der Gletscherfronten des Gebietes mit Lagen auf Photographien von vor 50 Jahren keinerlei Bewegung der Fronten oder merkliche Grössenveränderungen während der letzten 50 Jahre erkennen lässt.

Radio-Carbon-Datierungen von mumifizierten Seehund-Gerippen aus den Gletschervorfeldern zeigen, dass die Gletscher für mindestens 1 ooo Jahre keinen grösseren Stand erreicht haben. Die jüngsten Moränen des Gebietes haben Eiskerne aus den bestehenden Gletschern. Radio-Carbon-Daten von Algen aus ausgetrockneten ephemeren Teichen im Gebiet der Eiskern-Moränen weisen den Moränen ein Alter von mindestens 6 ooo Jahren zu.

Fin weiterer Beweis für das hohe Alter der gletschernahen Moränen ist das Vorhandensein eines ziemlich regelmässigen Kleinrelief-Musters von Sandkeil-Polygonen sowohl auf den Endmoränen wie auf den Grundmoränen bis hin zur derzeitigen Gletscherfront. Untersuchungen zeigen, dass die Bildung solch wohlentwickelter Polygon-Muster hunderte, wenn nicht tausende von Jahren erfordert.

KNOWLEDge of the age of the moraines in any area is essential for a complete understanding of the glacial history and for possible correlation of events with other areas. When evaluating the parameters used to judge the age of moraines in Antarctica it is important to keep in mind the differences between moist temperate areas and arid polar areas from the standpoint of climate and glacier regimen and frost action, stream erosion and other geologic processes.

The McMurdo Sound area, Victoria Land, is perhaps the largest glacier-free area in Antarctica and one of the best localities on the continent to study past fluctuations of the edge of the continental ice sheet and the fronts of local alpine glaciers. The author, assisted by

* Publication authorized by the Director, U.S. Geological Survey. 
Norman R. Rivard, studied the glacial chronology of the ice-free area west, south and east of McMurdo Sound from i December i957 to io February I958, under the auspices of the United States National Committee of the International Geophysical Year. A statement of the glacial history of this area has been published (Péwé, $195^{8}[\mathrm{a}],[\mathrm{b}], \mathrm{1960}[\mathrm{a}],[\mathrm{b}],[\mathrm{c}]$ ).

Harrington and Speden (1960) recently published a photograph and note describing moraines near a lobe of Taylor Glacier on the west side of McMurdo Sound; they suggest that these moraines can possibly be correlated with moraines deposited during glacial advances in I 820, I 850 and 1890 in New Zealand and in the European Alps. The author believes that the

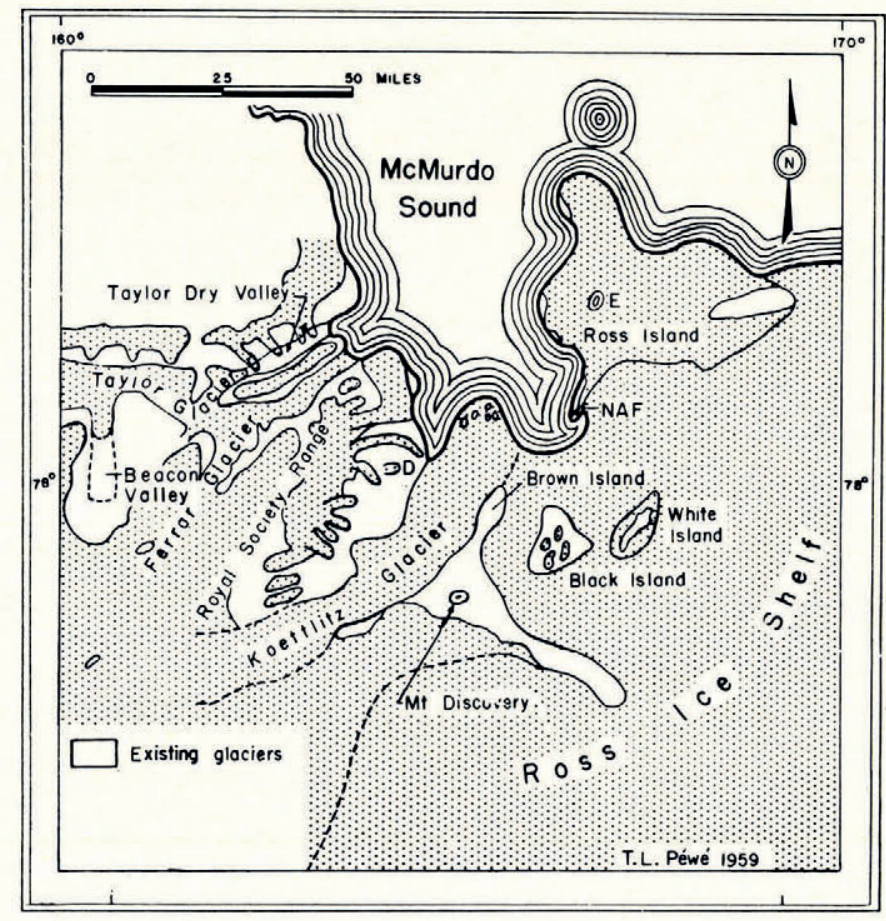

Fig. I. Sketch map of McMurdo Sound, Victoria Land, Antarctica showing the extent of existing glaciers, Letter symbols on map are: E. Mount Erebus; NAF. Williams Naval Air Facility; D. Davis Glacier. (Base modified after U.S. Navy Hydrographic Office Chart No. 6636 (Ross Sea) 3 rded., 23 September 1957)

end moraines described by Harrington and Speden in front of a lateral bulge of the upper Taylor Glacier* in Beacon Valley $\dagger$ (Fig. I) are not 50 or I oo yr. old but are perhaps thousands of years old and can be correlated with late Fryxell stage moraines elsewhere in the McMurdo Sound area (Péwé, ig6o [a]). The moraines in Beacon Valley were not visited by the author but were mapped in $195^{8}$ by using aerial photographs and extrapolating from moraines visited on the other side and in front of Taylor Glacier in Taylor Dry Valley.

The author believes these events are not "recent". In the adjoining ice-free valley north of Taylor Dry Valley, Clark ( 1960 ) repeatedly refers to the prolific very recent glaciations and conspicuous rapid recent wastage of the glaciers.

The author also was tempted to correlate "fresh-looking" moraines near glacier fronts,

* Incorrectly shown as Ferrar Glacier on all maps even though specifically named Taylor Glacier by Scott. Recent work of McKelvey and Webb (1959) shows that it is in reality the Taylor Glacier and not the Ferrar Glacier.

$\dagger$ So named by McKelvey and Webb (1959) from adjoining Beacon Heights. 
and even younger ice-cored moraines present on most glaciers adjacent to ice fronts, with the moraines from Recent advances in North America and New Zealand with which he was familiar. However, he now thinks that these "recent-looking" moraines throughout the icefree area of McMurdo Sound, including those figured by Harrington and Speden ( 1960 , fig. I) (Fig. 2) are considerably older.

The following is now suggested as evidence for the antiquity of the moraines figured by

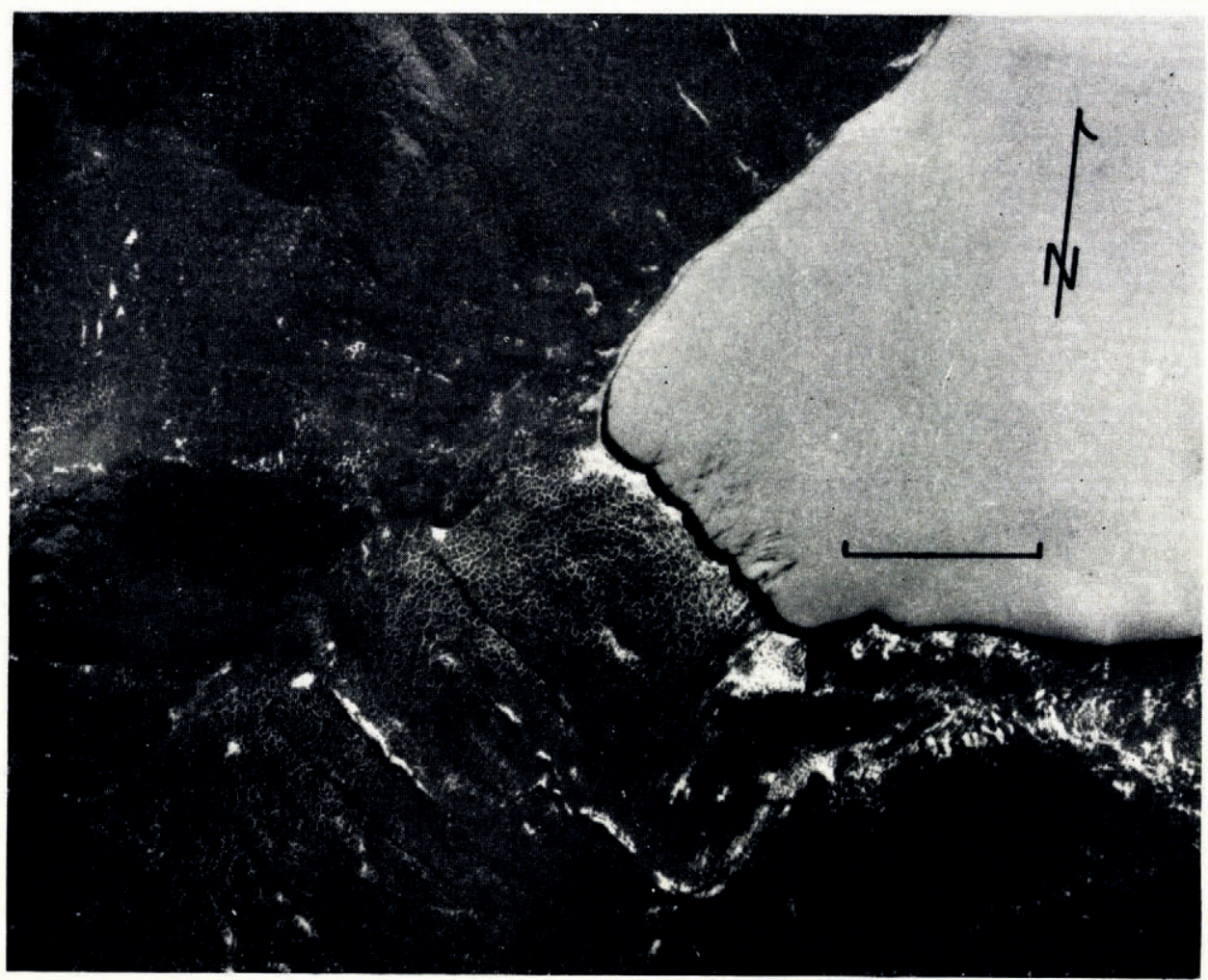

Fig. 2. Vertical air photograph of the lower end of Beacon Valley and part of Taylor Glacier, McMurdo Sound area, Victoria Land, Antarctica. The valley floor is covered with a micro-relief pattern of sand-wedge polygons formed in end and ground moraines. End moraines extend transversely across the valley roughly parallel to the vertical ice front. The black bar on the right represents a distance of approximately $500 \mathrm{~m}$. (Photograph by U.S. Navy, 6 December I956. Identification No. ${ }_{5} 6$, $\left.F-32, V X-6, \operatorname{USN}_{4} / 60\right)$

Harrington and Speden (196o, p. 652) and for similar moraines in the McMurdo Sound area.

It has long been held that the regimen of Antarctic glaciers is sluggish. The precipitation in the area, as well as the continent in general, is very slight (Flowers, 1958), and ablation of glacial ice is low because of the cold climate. Péwé photographed the positions of many glacier fronts in the McMurdo Sound area in 1957 and $195^{8}$ and compared them with the respective positions of the fronts as photographed from exactly the same localities $46 \mathrm{yr}$. earlier by Taylor (1922). A photo-comparative study of many glacier fronts throughout the area, and further comparison of other glacial fronts with old maps, indicates that there is hardly a perceptible change in the positions of the glacial fronts and in the thicknesses of the lower ends of these 
glaciers in half a century (Péwé, r $95^{8}[\mathrm{c}]$ ). One of the fronts so studied was the present terminus of Taylor Glacier (Taylor, 1922, fig. 3), about 25 miles from the Beacon Valley bulge described by Harrington and Speden (1960). If all rephotographed glacier fronts in the McMurdo Sound area (including the terminus of Taylor Glacier) show no movement of their fronts and no appreciable thinning or thickening of their lower ends during the last $50 \mathrm{yr}$., it would seem unlikely that the front of the lateral bulge of Taylor Glacier into Beacon Valley would have retreated $0 \cdot 5^{-1} \cdot 0$ mile in the last $5^{0}$ or $100 \mathrm{yr}$.

The almost complete absence of organic material which can be dated by the radiocarbon method seriously handicaps a quantitative approach to the age of moraines and glacier fronts in this area. A unique organic material that does shed some light on the problem is that of the mummified seal carcasses found in the glacier-free area many miles from the sea (Péwé and others, 1959). It is believed that these seals crawled miles onto the land and died for lack of food. The cold, arid climate prevented decay and the carcasses have been slowly eroding away by wind action over a long period. Radiocarbon dating of carcasses (Table I) indicates that the seal remains range in age from 600 to 2,0oo yr. (Péwé and others, 1959). These dates indicate that the ice has not been over the area where the seals lay for this interval of time.

TABLE I

\begin{tabular}{ll} 
Lab. No. & \multicolumn{1}{c}{ Locality } \\
W-85 & $\begin{array}{l}\text { I mile east of Bonney } \\
\text { Lake }\end{array}$ \\
L-462B & $\begin{array}{l}\text { I mile east of Bonney } \\
\text { Lake, Taylor Dry Val- } \\
\text { ley } \\
\text { On-462E } \\
\text { On ice surface of Bon- } \\
\text { Valley }\end{array}$
\end{tabular}

\begin{tabular}{|c|c|c|c|}
\hline $\begin{array}{l}\text { Elevation } \\
\text { ft. a.s.l. }\end{array}$ & Description & Age & Remarks \\
\hline 365 & Well-preserved carcass & $660 \pm 300$ & $\begin{array}{l}\text { Written communica- } \\
\text { tion } 28 \text { October I } 959 \\
\text { from Meyer Rubin, } \\
\text { U.S. Geological Survey }\end{array}$ \\
\hline 1,640 & Weathered fragment & I,600-2,600 & Péwé and others, 1959 \\
\hline 300 & Well-preserved carcass & $600-1,720$ & $\begin{array}{l}\text { Written communica- } \\
\text { tion i } 6 \text { April I } 959 \text { from } \\
\text { E. A. Olson, Lamont } \\
\text { Geological Observatory }\end{array}$ \\
\hline
\end{tabular}

Although these dated remains give a minimum date for the retreat of ice, these carcasses were found at least a mile from a glacier front. Old carcasses that occur near to ice fronts would better support the suggestion that the ice fronts have not retreated recently. To further support this suggestion, a part of a carcass of a small crabeater seal that was found on the ground about $100 \mathrm{ft}$. $(30.5 \mathrm{~m}$.) from the vertical face of the front of Davis Glacier in Davis Valley was submitted for testing. This carcass was at an elevation of $1,170 \mathrm{ft}$. $(356.6 \mathrm{~m}$.) above sealevel and appeared to be of an immature individual inasmuch as it was only 24 in. $(0.6 \mathrm{I} \mathrm{m}$.) long. It was dried, wind polished, and "tough". The skull and teeth were weathered and some of the bones of the flippers were beginning to be "weathered out". The hair on the bottom of the carcass was well preserved. The age of a piece of the flipper of this mummified seal carcass was determined by radiocarbon dating to lie between 200 and $1,200 \mathrm{yr}$. ${ }^{*}$ This indicates that the area immediately adjacent to the front of Davis Glacier has not been covered by the ice for about 200 to $500 \mathrm{yr}$. and the ice has not, therefore, retreated from this spot recently. This evidence supports the hypothesis that glacial fronts in the other valleys of this area have not retreated during the last 50 to $100 \mathrm{yr}$.

The evidence for the latest glacial advance in the McMurdo Sound area is the presence of widespread ice-cored moraines adjacent to the fronts of many glaciers. Such ice-cored moraines

* An apparent age of $1,200 \mathrm{yr}$. was obtained on the sample using 1890 wood as a standard; because of the different concentration of ${ }^{14} \mathrm{C}$ in Antarctic waters it is believed that in all probability the seal sample is less than $500 \mathrm{yr}$. old and perhaps less than $200 \mathrm{yr}$. (written communication from W. S. Broecker, Lamont Geological Observatory, io November 1960 ). 
are thought to be only 100 or $200 \mathrm{yr}$. old in other parts of the woild (Péwé and others, unpublished); however, 1 adiocarbon dates of algae from extinct ephemeral ponds* that formerly existed on the shifting topography of the ice-cored moraine of the Koettlitz Glacier indicate that the moraine is at least 2,500 to 6,000 yr. old (Péwé, I96o[a]). Undoubtedly, climatic conditions here are such as to pe eserve ice-cored moraines for an incredible length of time compared with temperate or subarctic latitudes. Such an age for ice-cored moraines adjacent to glacial fronts also suggests that it has been a considerable length of time since the glaciers have retreated an appreciable distance.

The main argument by Blake and Hollin (1960) against the young age of the moraines described by Harrington and Speden is that a polygonal micro-relief pattern on the ground is uniformally well developed over the entire valley floor in question (Fig. 2). Harrington and Speden (196I) have replied to this comment. The author wrote informally to Harrington in I 960 pointing out that the polygons suggested a much older age for moraines than mentioned by him and Speden ( 1960 ).

It appears, from the reply by Harrington and Speden (I96I), that there is not a clear understanding of the origin and development of the "polygons" present in the McMurdo Sound area. The present author studied the polygons intensively for one season and observed similar polygons in Alaska and Canada for several years (Péwé, 1952, I957, in press). In both polar areas the polygons are generally io to $20 \mathrm{~m}$. in diameter.

Péwé (1959, in press) believes that the polygons in both Alaska and Antarctica are caused by the formation of seasonally recurring thermal contraction cracks in the perennially frozen ground-cracks which are produced by the great changes in temperature from summer to winter. The intense stresses generated by a drop in ground temperature (Lachenbruch, 1959) result in the formation of a polygonal network of contraction cracks. It has been shown by Leffingwell (1915, 1919) that hoar frost, ice crystals and melt water periodically fill or partly fill the cracks to produce a narrow vein of ground ice in the permafrost of the northern cold areas. This ice vein is not destroyed by the expansion of ground in the summer and provides a zone of weakness for repeated cracking and ice growth in subsequent winters. Eventually a polygonal network of massive foliated ice masses (wedges) exists in the ground.

Because of the extreme aridity in Antarctica, especially of the west side of McMurdo Sound, the periodic contraction cracks are filled with clean sand which filters down from above in summer. Repeated cracking and filling produces a wedge-shaped body of sand instead of ice as in the northern polar areas (Fig. 3). These wedge-shaped masses of sand have been termed sand-wedge polygons by Péwé (1959, fig. 2). The polygonal pattern itself has also been referred to as tesselations by Taylor (I922).

The ice wedge or sand-wedge polygons should not be confused with patterned ground formed by sorting processes and which are different from contraction polygons in size, rate of formation and cycle of development. Such confusion has long been apparent in geology and engineering. The size and configuration of the contractional polygon is dependent upon the nature of material, moisture content and direction of tensile stresses (Black, 1952), as well as the rate and total amount of cooling (Lachenbruch, I959).

Sand-wedge polygons could conceivably form during the first year after the ground was uncovered from glacial ice. The initial size and form would not change rapidly, if at all. Later, some polygons can split into smaller contractional polygons. Ordinarily, the cracks open at about the same place every winter and the overall shape and size is preserved for thousands of years.

With this understanding of the origin of the contraction crack polygon it is obvious that the main change with time is the filling of the crack with ice or sand depending upon the environment (Péwé, I959, p. 550). The wedge filling constantly grows wider and the sediment

* For a colored photograph of such a pond in the McMurdo Sound area see National Geographic Magazine, Vol. I 16, No. 4, I959, p. 547. 
adjacent to the wedge is tilted upward more and more to form a raised edge on the surface around the polygon (Fig. 3). In Antarctica the raised edges do not rise more than $0.33-$ $0.50 \mathrm{~m}$. above the ground surface because slumping and wind erosion act to wear down the ridge.

Neither the height of the ridge nor the size of the polygon can be used reliably to indicate age of the polygons. The width of the sand-wedge is a reliable index if the sand supply is stable. Very young polygons may have a sand-wedge of only a few millimeters in thickness but very

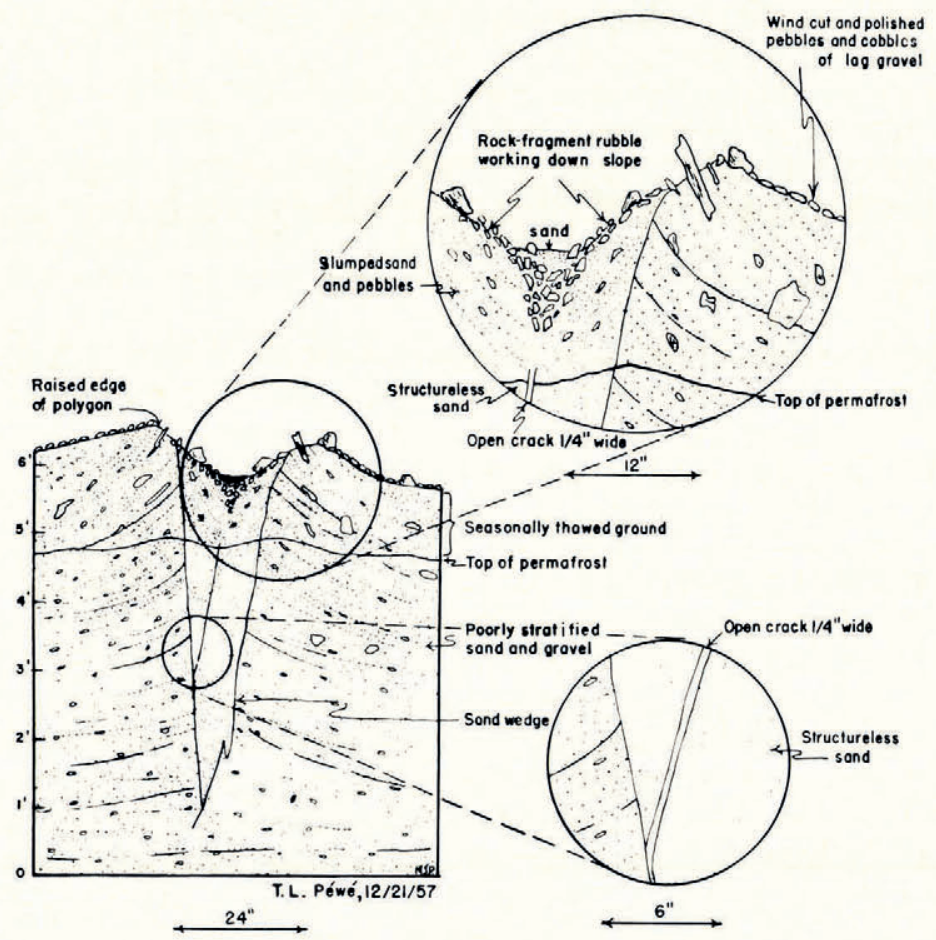

Fig. 3. Diagrammatic sketch of a sand-wedge near Lake Fryxell, lower Taylor Dry Valley, McMurdo Sound, Antarctica. (Reproduced by courtesy of the Editor, American Journal of Science)

old ones may have wedges $\mathrm{I}$ or $2 \mathrm{~m}$. wide. Exposures of the wedge fillings are rare and therefore this index of age is of limited use.

Because of the lack of exposure of wedge fillings another method was used to determine relative age of polygons in the McMurdo Sound area. The wider the wedge filling the greater was the distance between the crests of the raised edges of the polygonal furrows (Fig. 3). Many measurements were taken of crest distances across the trenches of polygonal furrows in many types of sediment, on many different land forms, and in different ice-free valleys. On the most recent of small flood plains on the west side of McMurdo Sound "normal" sized polygons are formed. The distance from crest to crest across the polygonal trench is 6-12 cm. These small furrows are too small to accumulate snow during a light snow fall, and, therefore, to outline the polygons as commonly seen in the area (Fig. 2) (Péwé, 1959, fig. I). These polygons on the most recent flood plains appear the same as they did 50 yr. ago when photographed by Taylor. It is obvious that it takes more than $5^{0} \mathrm{yr}$., and no doubt thousands of 
years to have the intersecting shallow furrows or trenches widen to $\mathrm{I}$ to $2 \mathrm{~m}$. (when measured at the crest edges). Such widths are common on the moraines of the Fryxell and Taylor stages (Fig. 4). During the early summer such trenches are commonly filled with snow and the surface of the ground has the appearance of a large mosaic pavement.

The well-developed polygonal ground is excellently shown in the front of the lobe of Taylor Glacier described by Harrington and Speden ( I96o, fig. I) (Fig. 2). These polygons were not visited on the ground but from air photographs they look similar to polygons in the lower part

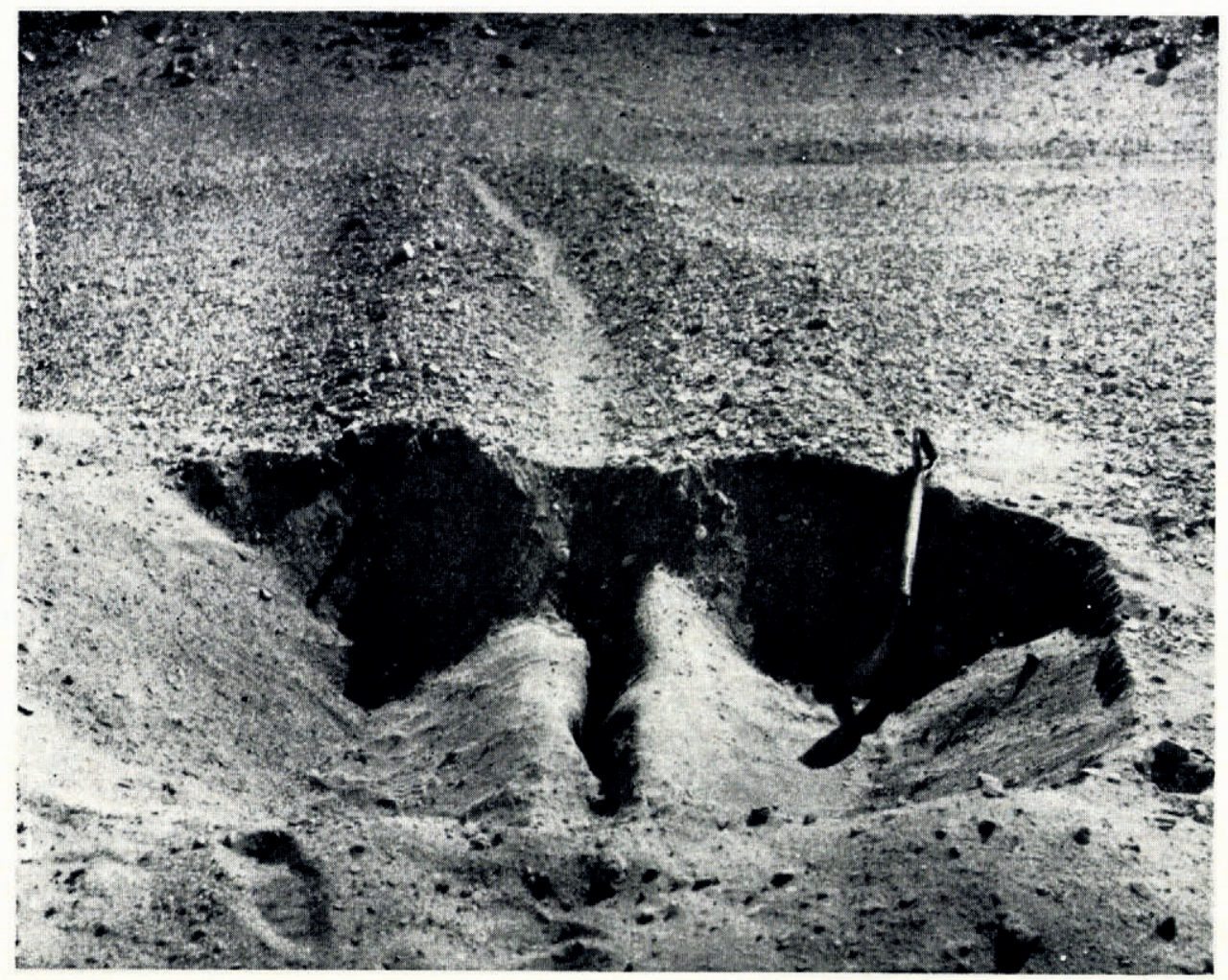

Fig. 4. Transverse section across the raised edges of sand-wedge polygons in glacial drift near Lake Bonney, upper Taylor Dry Valley, Mc Murdo. Sound, Antarctica. The excavation extends down to the top of the permafrost table. A seasonal contraction crack under a sand-filled trough is shown in the foreground. Lag gravel covers the ground surface. (Photograph by T. L. Péwé, 18 December 1.957)

of Taylor Dry Valley. It is here suggested that the polygons shown in Figure 2 alongside of the lobe of Taylor Glacier have furrows which are one or more meters across at the ridge crest and therefore are of considerable antiquity, hundreds if not thousands of years old. In fact, McKelvey and Webb (r959) state that the polygons on this valley floor are bounded by peripheral troughs "as deep as 4 feet".

\section{Conclusion}

In conclusion, it is believed that the well-developed series of small moraines displayed in front of a lobe of Taylor Glacier are much older than the $5^{\circ}$ or $\mathrm{r} 00 \mathrm{yr}$. suggested by Harrington 
and Speden and that these and other "recent-looking" moraines in the McMurdo Sound area, Victoria Land in general are thousands of years old. This is supported by the following:

(I) The photographic record shows little or no ice front retreat in the area during the last $50 \mathrm{yr}$.

(2) Radiocarbon dates of mummified seal carcasses suggest no ice retreat for at least the last $\mathrm{I}, 000 \mathrm{yr}$.

(3) The youngest moraines are in many places ice-cored and at least 6,ooo yr. old.

(4) Well-developed sand-wedge polygons with interpolygon furrows $\mathrm{I}-2 \mathrm{~m}$. wide indicate a glacier-free area for hundreds if not thousands of years.

\section{MS. received 20 December 1960}

\section{REFERENCES}

Black, R. F. 1952. Polygonal patterns and ground conditions from aerial photographs. Photogrammetric Engineering, Vol. 18, No. 1, p. 123-34.

Blake, W., ir., and Hollin, J. 1960. Recent moraines of a lobe of the Taylor Glacier, Victoria Land, Antarctica. Journal of Glaciology, Vol. 3, No. 28, p. 792-93. [Letter.]

Clark, R. H. r 960 . Geological work in Antarctic dry valleys. Report of the twenty-first International Geological Congress, Part XXI, p. 105-09.

Flowers, E. C. 1958. Weather at U.S.-I.G.Y. Antarctic stations during 1957. Transactions. American Geophysical Union, Vol. 39 , No. 5, p. 997-roor.

Harrington, H. J., and Speden, I. G. I96o. Recent moraines of a lobe of the Taylor Glacier, Victoria Land. Antarctica. Fournal of Glaciology, Vol. 3 , No. 27, p. 652-53. [Letter.]

Harrington, H. J., and Speden, I. G. 1961. Recent moraines of a lobe of the Taylor Glacier, Victoria Land, Antarctica. Fournal of Glaciology, Vol. 3, No. 29, p. 946-48. [Letter.]

Lachenbruch, A. H. 1959. Contraction theory of ice-wedge polygons. Bulletin of the Geological Society of America, Vol. 7o, No. 12, Pt. 2, p. 1796.

Leffingwell, E. de K. 1915. Ground-ice wedges-the dominant form of ground-ice on the north coast of Alaska. fournal of Geology, Vol. 23, No. 7, p. 635-54.

Leffingwell, E. de K. 1919. The Canning River region, northern Alaska. U.S. Geological Survey. Professional Paper Iog.

McKelvey, B. C., and Webb, P. N. 1959. Geological investigations in South Victoria Land, Antarctica. Part II. Geology of upper Taylor Glacier region. New Zealand Journal of Geology and Geophysics, Vol. 2, No. 4, p. 718-28.

Péwé, T. L. 1952. Geomorphology of the Fairbanks area, Alaska. [Ph.D. thesis, Stanford University, California.]

Péwé, T. L. 1957. Permafrost and its effect on life in the north. (In Hansen, H. P., ed. Arctic biology: I8th annual biology colloquium proceedings, 1957. Corvallis, Oregon, Oregon State College, p. 12-25.)

Péwé, T. L. 1958[a]. Pleistocene glacial chronology of the McMurdo Sound region, Antarctica. (In Symposium on Antarctic research. Wellington, N.Z., Department of Scientific and Industrial Research, p. 1-3.)

Péwé, T. L. 1958[b]. Quaternary glacial geology of the McMurdo Sound region, Antarctica-a progress report. I.G.Y. Glaciological Report Series (New York, I.G.Y. World Data Center A, Glaciology, American Geographical Society), No. I, p. VI-I-4.

Péwé, T. L. 1958[c]. Glacier fluctuation between 1911 and $195^{8}$ in the McMurdo Sound region, Antarctica. Bulletin of the Geological Society of America, Vol. 69, No. 12, p. 1755-56.

Péwé, T. L. 1959. Sand-wedge polygons (tesselations) in the McMurdo Sound region, Antarctica-a progress report. American fournal of Science, Vol. 257 , No. 8, p. $545^{-52}$.

Péwé, T. L. 196o[a]. Multiple glaciation in the McMurdo Sound, Antarctica-a progress report. Ohio State University Research Foundation. Report $825^{-2}-$ Part IX, p. I-27.

Péwé, T. L. I $960[\mathrm{~b}]$. Glacial history of the McMurdo Sound region, Antarctica. Report of the twenty-first International Geological Congress, Part IV, p. 7 1-8o.

Péwé, T. L. $1960[\mathrm{c}]$. Multiple glaciation in the McMurdo Sound region, Antarctica. Journal of Geology, Vol. 68, No. 5 , p. $49^{8-5}$ i 4 .

Péwé, T. L. In press. Ice wedges in permafrost, lower Yukon River area near Galena, Alaska. Biuletyn Peryglacjalny.

Péwé, T. L., and others. 1959. Mummified seal carcasses in the McMurdo Sound region, Antarctica, by T. L. Péwé, N. R. Rivard and G. A. Llano. Science, Vol. 130, No. 3377, p. 716.

Péwé, T. L., and others. Unpublished. The antiquity of ice-cored moraines in the McMurdo Sound area, Antarctica, by T. L. Péwé, P. V. Sellmann and R. E. Church.

Taylor, T. G. 1922. The physiography of the McMurdo Sound and Granite Harbour region. London, Harrison. (British Antarctic (Terra Nova) Expedition, 1910-13.) 